\title{
Comparison of Unmanned Aerial Vehicle Platforms for Assessing Vegetation Cover in Sagebrush Steppe Ecosystems
}

\author{
Robert P. Breckenridge, ${ }^{1}$ Maxine Dakins, ${ }^{2}$ Stephen Bunting, ${ }^{3}$ Jerry L. Harbour, ${ }^{4}$ and Sera White ${ }^{5}$ \\ Authors are ${ }^{1}$ Environmental Scientist and ${ }^{5}$ Geospatial Scientist, Idaho National Laboratory, Idaho Falls, ID 83415, USA; ${ }^{2}$ Associate Professor, \\ Environmental Science Program, and ${ }^{3}$ Professor, Department of Rangeland Ecology and Management, University of Idaho, Moscow, ID 83844, USA; \\ and ${ }^{4}$ Senior Scientist, Epsilon Systems Solution, Inc., Albuquerque, NM 87106, USA.
}

\begin{abstract}
In this study, the use of unmanned aerial vehicles (UAVs) as a quick and safe method for monitoring biotic resources was evaluated. Vegetation cover and the amount of bare ground are important factors in understanding the sustainability of many ecosystems. Methods that improve speed and cost efficiency could greatly improve how biotic resources are monitored on western lands. Sagebrush steppe ecosystems provide important habitat for a variety of species including sage grouse and pygmy rabbit. Improved methods of monitoring these habitats are needed because not enough resource specialists or funds are available for comprehensive on-the-ground evaluations. In this project, two UAV platforms, fixed-wing and helicopter, were used to collect still-frame imagery to assess vegetation cover in sagebrush steppe ecosystems. This paper discusses the process for collecting and analyzing imagery from the UAVs to 1) estimate percentage of cover for six different vegetation types (shrub, dead shrub, grass, forb, litter, and bare ground) and 2) locate sage grouse using representative decoys. The field plots were located on the Idaho National Laboratory site west of Idaho Falls, Idaho, in areas with varying amounts and types of vegetation cover. A software program called SamplePoint was used along with visual inspection to evaluate percentage of cover for the six cover types. Results were compared against standard field measurements to assess accuracy. The comparison of fixed-wing and helicopter UAV technology against field estimates shows good agreement for the measurement of bare ground. This study shows that if a high degree of detail and data accuracy is desired, then a helicopter UAV may be a good platform to use. If the data collection objective is to assess broad-scale landscape level changes, then the collection of imagery with a fixed-wing system is probably more appropriate.
\end{abstract}

\section{Resumen}

En este estudio se evaluó el uso de vehículos aéreos no tripulados (VANT) como un método rápido y seguro para monitorear recursos bióticos. La cubierta vegetal y la cantidad de suelo desnudo son factores importantes para entender la sustentabilidad de varios ecosistemas. Métodos que mejoren la rapidez y el costo podrían mejorar la manera en que los recursos bióticos de las tierras del oeste son monitoreados. El ecosistema de estepa de artemisa provee hábitat para varias especies que incluyen al ganso sage y conejo pigmeo. Es necesario mejorar los métodos de monitoreo de estos hábitat porque no hay suficientes especialistas en recursos o fondos disponibles para evaluaciones completas en el terreno. En este proyecto, se utilizaron dos plataformas de VANT, alas fijas y helicóptero para recolectar imágenes fotográficas para evaluar la cubierta vegetal en un ecosistema de estepa de artemisa. En este artículo se discute el proceso de recolección y análisis de imágenes de un VANT para 1) estimar el porcentaje de cubierta de seis diferentes tipos de vegetación (matorral, matorral seco, zacate, hierbas, mantillo y suelo desnudo) y 2) ubicar gansos sage usando señuelos. Las parcelas experimentales se ubicaron en el Laboratorio Nacional de Idaho sitio localizado en Idaho Falls, Idaho en áreas con diferentes cantidades y tipos de cubierta vegetal. Se uso el programa de software SamplePoint junto con inspecciones oculares para evaluar el porcentaje de cubierta de seis tipos de cubiertas. Los resultados se compararon contra medidas de campo estándar para evaluar su precisión. La comparación de la tecnología de helicóptero VANT y alas fijas contra estimaciones de campo muestra buena relación para las medidas de suelo desnudo. El estudio muestra que sí se requiere alto grado de detalle y precisión en los datos el helicóptero VANT podría ser una buena plataforma para usarse. Pero sí el objetivo de recopilación de datos, es evaluar a gran escala los niveles de cambio en el paisaje entonces, la recopilación de imágenes con el sistema de alas fijas es probablemente más apropiado.

Key Words: bare ground, fixed-wing, helicopter, landscape, monitoring, remote sensing

\footnotetext{
Work was supported through Idaho National Laboratory's Laboratory Directed Research and Development Program under Dept of Energy, Idaho Operations Office Contract DE-AC07-05ID14517. This submitted manuscript was authored by a contractor of the US Government under Dept of Energy Contract DE-AC07-05ID14517. Accordingly, the US Government retains and the publisher, by accepting the article for publication, acknowledges that the US Government retains a nonexclusive, paid-up, irrevocable, world-wide license to publish or reproduce the published form of this manuscript, or allow others to do so, for US Government purposes.

US Dept of Energy Disclaimer: This information was prepared as an account of work sponsored by an agency of the US Government. Neither the US Government nor any agency thereof, nor any of their employees, makes any warranty, express or implied, or assumes any legal liability or responsibility for the accuracy, completeness, or usefulness of any information, apparatus, product, or process disclosed, or represents that its use would not infringe privately owned rights. References herein to any specific commercial product, process, or service by trade name, trademark, manufacturer, or otherwise, does not necessarily constitute or imply its endorsement, recommendation, or favoring by the US Government or any agency thereof. The views and opinions of authors expressed herein do not necessarily state or reflect those of the US Government or any agency thereof.

At the time of the research, Breckenridge was Manager of Idaho National Laboratory's Ecological Sciences Dept, Idaho Falls, ID, USA.

Correspondence: Robert Breckenridge, Idaho National Laboratory, PO Box 1625, Idaho Falls, ID 83415-3405, USA. Email: Robert.Breckenridge@inl.gov

(0 Battelle Energy Alliance, LLC, 2011
}

Manuscript received 18 February 2010; manuscript accepted 26 May 2011 


\section{INTRODUCTION}

Vegetation cover is an important factor in maintaining the sustainability of rangeland biotic resources. Cover type data provide important information relative to ecological structure and processes such as nutrient and energy cycling, erosion, fuel management, and desertification (National Research Council 1994; Mouat and Hutchinson 1995; Carroll et al. 1999; Pyke et al. 2002; Crawford et al. 2004; Pellant et al. 2005). Inventory and monitoring requirements to meet land management mandates and support legal challenges on federal lands in the western United States are monumental tasks. Arid lands in the contiguous United States account for about 37\% of the lands west of the $95^{\circ} \mathrm{W}$ longitude (Bender 1982). Resource managers are facing tremendous challenges because there are not enough natural resource specialists or funds for ground surveys on many of these lands. New approaches are needed to collect information to address challenges related to the need for frequent acquisition of accurate broad-scale data.

Using manned aircraft to monitor and inventory western lands, when pilots are often required to fly slowly and low in remote areas, is very risky and has resulted in fatal accidents. Data compiled for 1990-2002 from the National Transportation Safety Board aviation accident database and synopses compiled by the Idaho Fish and Game Department show that flying aircraft for wildlife and fisheries applications has resulted in 2.6 fatalities per yr for fixed-wing aircraft; 1.3 survey-related incidents have occurred per yr for helicopters, resulting in one fatality every 4 yr (Zager 2006; National Transportation Safety Board 2007). Satellite-based remote sensing systems provide an option; however, these systems have potential issues with cost and accuracy at the sub-meter level and are impacted by cloud cover. A near-earth system that provides accurate data at a reasonable risk and cost is needed to improve monitoring on western lands.

Unmanned aerial vehicle (UAV) platforms are a potential option for collecting near-earth data in almost real time (Quiter and Anderson 2001; Rango et al. 2009; Breckenridge and Dakins 2011). UAV technology has matured from many years of using UAVs as hobby aircraft (Hardin and Jackson 2005; Hardin et al. 2007). The military has also used this technology to collect reconnaissance information without putting humans in harm's way. The major advancement in UAVs has come about with the miniaturization of electronics in specialized cameras and video, navigational, and global positioning systems (GPS). It is now possible to equip a UAV to fly a specific flight path and automatically trigger the camera to collect data at predefined GPS locations. In addition, a realtime video feed can be sent to a receiver on the ground. Some UAVs can be flown using autonomous navigational systems, and many of the fixed-wing platforms can fly for several hours, depending on engine configuration. These platforms can carry a variety of sensors to capture imagery of the resources (i.e., invasive species) on the ground (Hardin et al. 2007). (UAVs do have payload limitations, however, so sensors and cameras need to be relatively light.) This imagery provides a unique opportunity and challenge for scientists and managers tasked with collecting inventory and monitoring data to ensure proper management of biotic resources on federal lands (Rango et al. 2006, 2009).
This study examined the use of fixed-wing and helicopter UAV technology to monitor cover types and selected biotic resources on rangelands. The study had the following four objectives:

1) Assess the feasibility of using UAV technology to collect imagery useful in evaluating six cover types (shrub, dead shrub, grass, forb, litter, and bare ground) in sagebrush steppe ecosystems.

2) Compare the relative accuracy of values collected and processed from UAV technology with values from field measurements.

3) Determine the feasibility of using UAV imagery to identify the presence and sex of birds using decoys to represent male and female sage grouse (Centrocercus urophasianus) in sagebrush communities.

4) Compare the level of effort for collecting vegetation cover data from UAV and field methods.

As stated, one of the most observed features of a given community is its physical structure (Smith 1990). Total vegetation cover is an important part of a rangeland structure and is used to assess the condition of rangelands (SRM 1995; Pyke et al. 2002; Pellant et al. 2005); it also plays an important role in understanding the desertification process (Mouat and Hutchinson 1995). Total vegetation cover is the proportion of ground occupied by a perpendicular projection to the ground from the outline of the aerial parts of the plant species (Brower et al. 1990). Typically, coverage can be visualized as the proportion of ground covered by the different cover types, as viewed from above. For this reason, UAVs provide a good potential platform for coverage measurements.

Vegetation cover is usually evaluated by a several-person field crew using one of a variety of field methods, such as linetransect or quadrat sampling (Bonham 1989; Brower et al. 1990; USDI-BLM 1997). The accuracy of conventional groundcover methods compared with emerging automated methods has been recently evaluated (Booth and Tueller 2003; Booth et al. 2006b). Results indicate that conventional techniques have significantly greater correlation $(\geq 92 \%$ agreement of measured to known) than algorithm-driven measurements from VegMeasure software (70\%; Johnson et al. 2003). The critical factor influencing the accuracy of a point-sampling method was the area of the contact point for the given method (Booth et al. 2006b). This supports findings from other researchers that point sampling with a minimal contact point results in the greatest measurement accuracy (Cook and Stubbendieck 1986). A number of different approaches exist for collecting both field and imagery values. Brower et al. (1990) and Bonham (1989) provide excellent discussions on the importance and methods for measuring vegetation cover to support research and management objectives. Breckenridge et al. (2006) provide a discussion of UAV technology and how it can be applied to the assessment of different cover types on rangelands.

Cover type, as used in this study, is defined as the material located above the soil surface, either live or dead. In cases where nothing is present, cover was referred to as bare ground. Forbs are an important cover type component because of their importance to wildlife (Connelly et al. 2000; Pedersen et al. 2003) and nutrient cycling (Smith 1990). The amount of litter 
and dead shrub are important factors for both fuels assessment for fire and as a deterrent against erosion from wind and rain (Pyke et al. 2002; Pellant et al. 2005). Dead shrub and litter also play a role in influencing ecological processes, such as nutrient and water cycling (Pyke et al. 2002). Bare ground has been identified by a group of rangeland scientists as one of the most important indicators for assessing long-term sustainability of western lands (Breckenridge et al. 1995; Maczko et al. 2004). Dead shrub, litter, and bare ground are important to the ecological condition of a site (National Research Council 1994). Environmental conditions also have a large effect on the response of a sagebrush steppe community to fire (Bunting et al. 1987). The vegetation type in more arid big sagebrush communities has been greatly influenced by annual grasses, particularly cheatgrass (Bromus tectorum; Bunting 2002).

Vegetation and cover analysis techniques are needed to support state-and-transition models, threshold evaluations, and rangeland health evaluations (Briske et al. 2005). Vegetation evaluation procedures must be able to assess continuous and reversible as well as discontinuous and nonreversible vegetation dynamics because both patterns occur and neither pattern alone provides a complete assessment of the vegetation dynamics on rangelands (Briske et al. 2005). Ecological thresholds describe a complex set of potentially interacting components rather than discrete boundaries in time and space (Briske et al. 2005). A specific disturbance or event (i.e., fire or drought) may trigger the crossing of a threshold that affects both structural and functional modifications during ecosystem transition of various time scales (Briske et al. 2005). Development of techniques that improve vegetation composition information available to support models and threshold evaluations at the landscape scale are critical for large-scale management of rangeland health.

\section{METHODS}

\section{Study Area Selection and Design}

The Idaho National Laboratory (INL) field site is located about $80 \mathrm{~km}$ west of Idaho Falls, Idaho. INL is a US Department of Energy (DOE) facility and was designated a National Environmental Research Park (NERP) in 1975 (DOE 1994). DOE encourages research and development activities on the NERP to support improved understanding of how human activities impact natural systems.

INL's landscape is dominated by a sagebrush steppe ecosystem with the unique aspects of a high-elevation, semiarid ecosystem (Whitford 1986; Rickard et al. 1988). These ecosystems often go through transitions from grasslands to shrub lands with numerous vegetation states, including extensive grasses; mixtures of grasses, forbs and sparse shrubs; and dense shrub cover (Walker 1993; Colket 2003). Activities such as grazing, burning, exotic weed infestation, and invasion and planting of nonnative species (i.e., crested wheatgrass [Agropyron cristatum]) can cause major changes to vegetation cover and have significant management implications (Knick and Rotenberry 1995).

Sagebrush steppe habitat is often dominated by a canopy of sagebrush. The absolute and relative amount of sagebrush, grasses, and forbs on a specific site varies with the subspecies of sagebrush, the ecological site potential, and the condition of the habitat. Sagebrush steppe communities that provide the best habitat to support sage grouse have shrub canopy cover between $15 \%$ and $25 \%$. Beyond these values, as shrub cover increases, the preference displayed by grouse declines (Connelly and Braun 1997; Nevada Wildlife Federation 2002). The importance of the forb component varies across the big sagebrush steppe communities. Forb richness increases with increasing precipitation; consequently, mountain big sagebrush (Artemisia tridentata subsp. vaseyana) steppe has a greater diversity of associated forbs than does Wyoming big sagebrush (A. tridentata subsp. wyomingensis) steppe (Bunting 2002).

The typical native vegetation on the INL site consists of a shrub overstory with an understory of perennial grasses and forbs. The most common shrubs are basin big sagebrush $(A$. tridentata subsp. tridententa) and Wyoming big sagebrush. Basin big sagebrush may be dominant or codominant with Wyoming big sagebrush on sites with deep soils or accumulations of sand on the surface. INL's vegetation communities have been very well described by a number of researchers (Anderson et al. 1996; Colket 2003; Mahalovich and McArthur 2004). INL has had a unique history relative to vegetation monitoring and has a number of long-term vegetation transects with established plots that have been monitored for over $50 \mathrm{yr}$ (Anderson and Holte 1981; French and Mitchell 1983; Anderson and Inouye 1999). The most common plants and communities have also been described by a number of researchers (Anderson and Holte 1981; French and Mitchell 1983; Anderson and Inouye 1999). The Stoller Corporation, through their Environmental Surveillance, Education, and Research Program, has developed an index to the plants found on the INL site (Forman and Hafla 2005). The most common native and exotic species are described in this index.

Data collection using the UAV platforms occurred during the spring and summer of 2005. INL has an established permit to fly under a Federal Aviation Administration Certification of Authorization (FAA-COA; FAA 2008; Rango and Laliberte 2010) and used it for this study. The selection of the study site was heavily influenced by the location of a UAV runway built within the NERP (Breckenridge 2007). The field plots were established within an area that is close to the runway (Fig. 1). Seven field plots were selected in areas that represented the diverse vegetation in both sagebrush- and grass-dominated communities that is typically seen in sagebrush steppe ecosystems. Orange lids were always used on the north end of the plots and subplots to make it easier to ensure orientation and identify images during analysis. Multiple orange lids were placed in the northwest corner of each plot to equal the plot number (i.e., Plot 7 had seven lids, including the lid on the subplot corner [shown in black in Fig. 2]).

To simulate sage grouse on a lek site, duck decoys were placed around the field plots (Fig. 2). Male decoys were "dressed" using 25.4-cm white plastic paint lids. The 25.4-cm size was based on a wildlife biologist's knowledge of the size of a male sage grouse white chest while making itself attractive to females and strutting on a lek. Female grouse were represented by female duck decoys with their natural camouflage. The decoys were either standing or lying down. The plots had between zero and seven decoys oriented in a manner that would typically be found on a natural lek site. Decoys were staked to the ground to minimize movement during strong winds. 

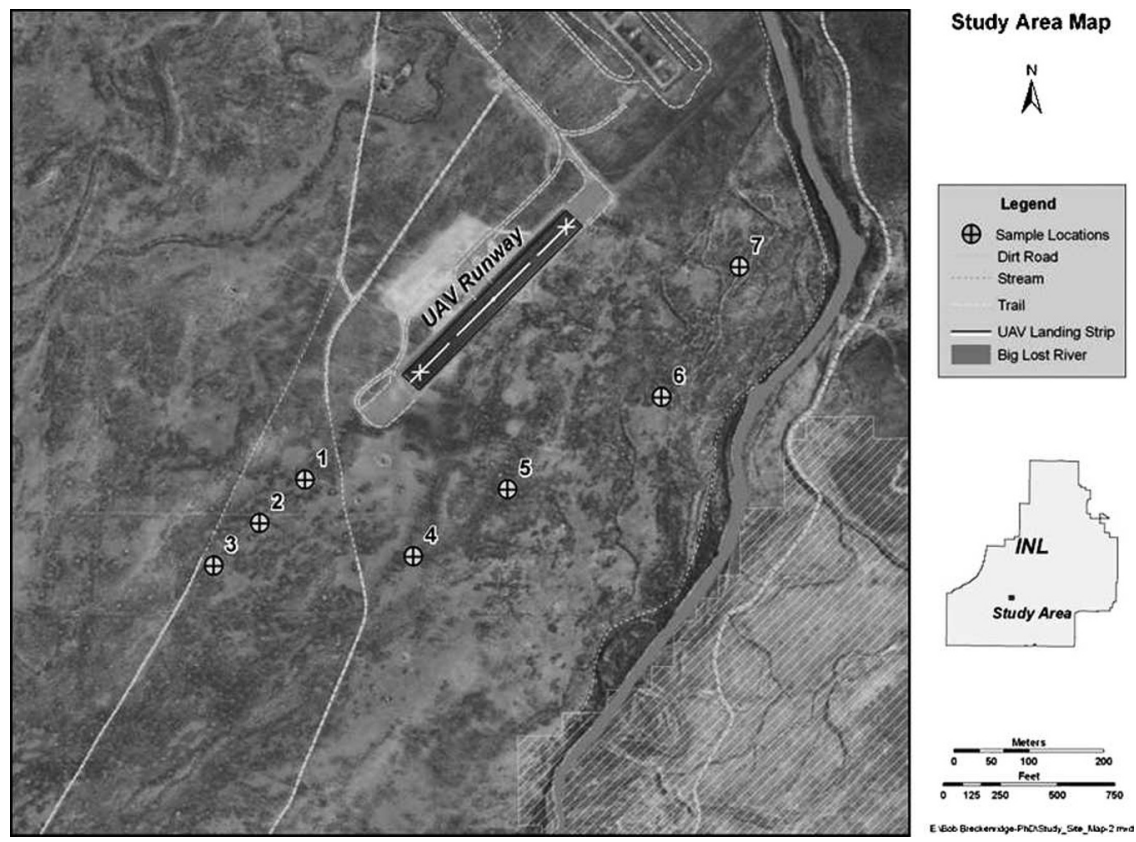

Figure 1. Study area map.

\section{Image Acquisition}

Fixed-Wing UAV. Imagery was acquired using two different UAV platforms. The first method used an APV-3 fixed-wing airplane with about a 3.7-m wing span made by RnR Products. This UAV platform has a payload limitation of $6.8 \mathrm{~kg}$ for

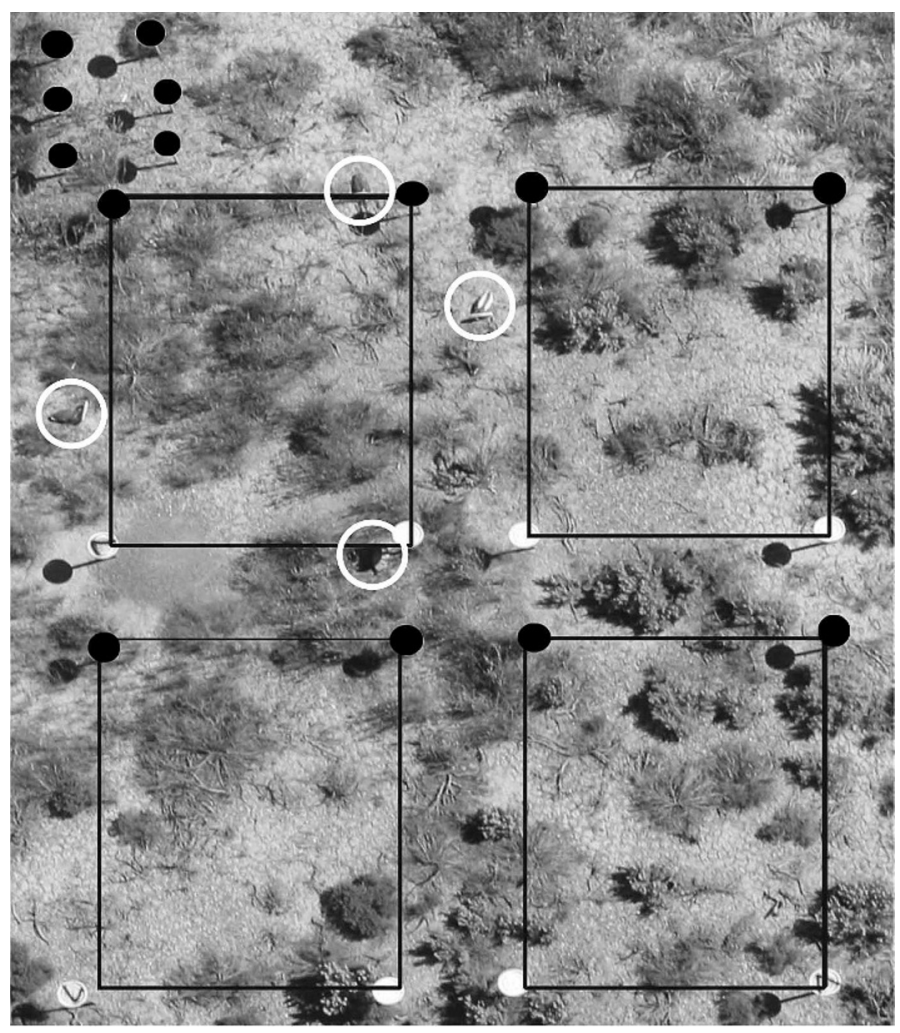

Figure 2. Field plot design for unmanned-aerial-vehicle image collection and analysis study. This image was taken at $76 \mathrm{~m}$ above ground level from a fixed-wing platform in July and shows the layout of plot 7 with four $3 \times 4 \mathrm{~m}$ subplots identified and three male and one female decoys (in the shadow of the lid; in white rings). fuel and equipment. The aircraft flew using an autonomous navigation system and carried a full-size camera equipped with a "through-the-lens" video feed connected to the ground base station through a remote frequency connection. The plane flew at 76,153 , and $305 \mathrm{~m}$ above ground level (AGL). Because of concerns with turning operations, the plane was not flown below $76 \mathrm{~m}$ AGL. The $153-\mathrm{m}$ and $305-\mathrm{m}$ imagery was collected 5-12 May 2005; the imagery from $76 \mathrm{~m}$ was collected on 14 July 2005. Manual controls were used during takeoffs and landings, which were conducted off the tricycle landing gear from the flat runway shown in Figure 1. During image acquisition, the plane was controlled with an autopilot system tied into a GPS; a portable computer on the ground with preprogrammed flight information controlled the plane through a remote frequency link. Fixed-wing flights typically lasted about 80 min and collected over 700 still images, plus videos.

The fixed-wing UAV images were collected by an 8megapixel Canon Mark II camera with a 50-mm lens (f-stop 1:1.8) mounted under the body of the UAV (Fig. 3a). The original approach to collecting images over each plot was to have the camera automatically triggered off the GPS system. The problem with this approach was that there was a slight lag between the time the GPS signal was sent to the camera and when the shuttle actually triggered. To overcome this situation, a measurement system was painted on the UAV runway. Images were then collected from the runway to calculate the lag between the GPS signal and the time that the image was recorded by the camera. To ensure at least one image of each plot was obtained, the camera was programmed to take a series of seven pictures in rapid succession. This approach proved very effective; often there were several images of a plot from which to select.

The fixed-wing platform was also outfitted with a throughthe-lens Canon camera video system that collected digital video at 30 frames $\cdot \mathrm{s}^{-1}$ as the plane flew. The video was transmitted down to a base station through a remote frequency connection 

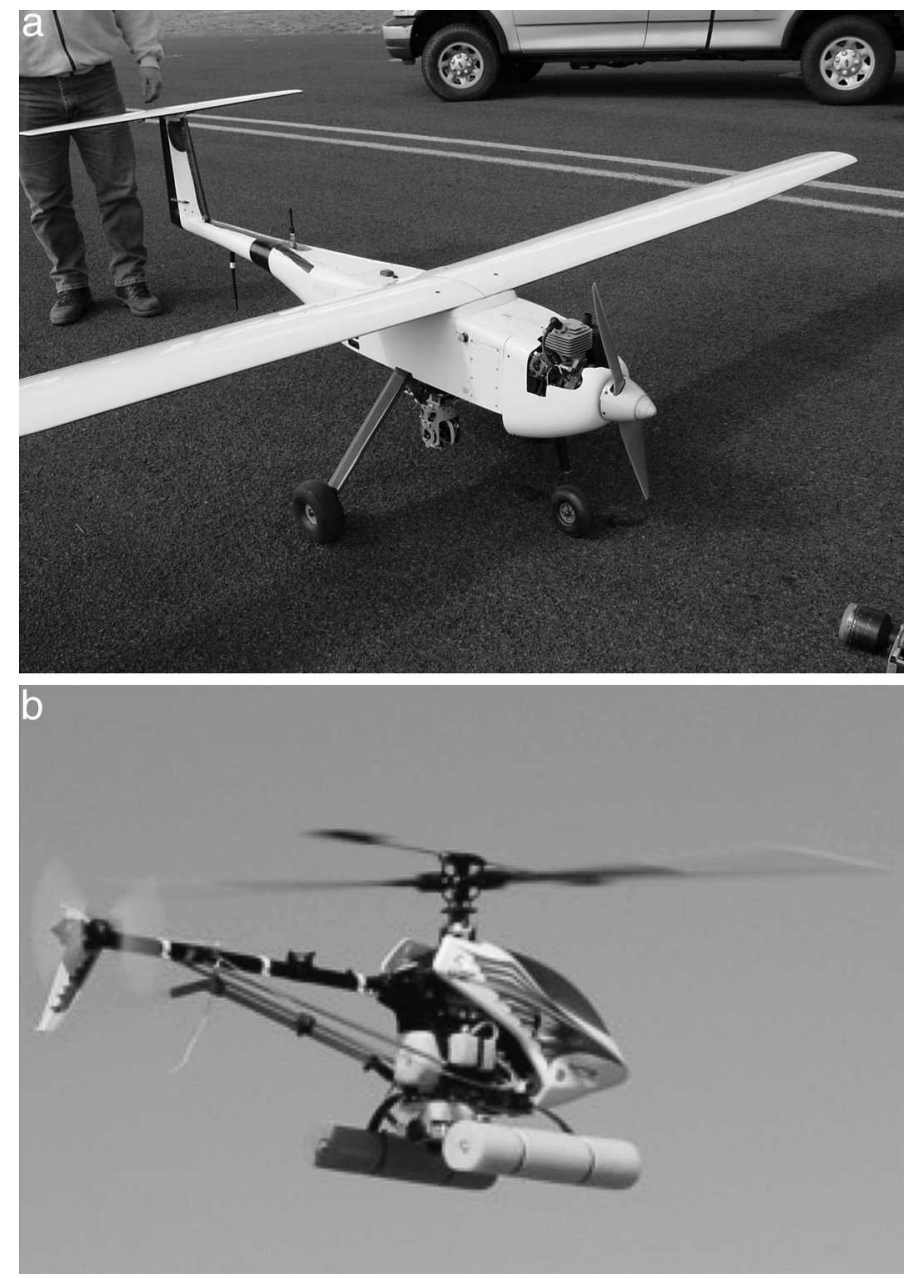

Figure 3. a, Fixed-wing unmanned aerial vehicle (UAV) by RNR Industries with camera mounted in a nadir position under the body; $\mathbf{b}$, helicopter UAV with camera mounted nadir under the center of the body.

and researchers on the ground could view the flight progress in real time. The video was used to help locate the field plots laid out on the ground. Video was captured on an analog recorder as a proof of concept and was evaluated to determine if it could identify vegetation cover and type as well as decoys.

The limiting factor for the fixed-wing platform was storage capacity for images downloaded to the camera. The fixed-wing UAV was able to handle a larger payload, including the fuel and the camera, than the helicopter UAV discussed in further detail below. The fixed-wing UAV could also be flown for $2 \mathrm{~h}$ to $4 \mathrm{~h}$, depending on how the engine and camera power system were configured.

Helicopter UAV. The second UAV platform was an X-Cell 60 model helicopter made by Miniature Aircraft carrying a small digital camera, a 4-megapixel, Olympus Stylus digital point-andshoot camera mounted on an aluminum frame under the nose of the helicopter (Fig. 3b). The camera captured nadir images when the helicopter was in a stable hovering position. (Nadir images are those taken directly over a field plot.) Images were acquired by an operator using a remote control trigger system. Imagery was collected at heights of 11-15 m AGL. Several different methods were tried for locating the helicopter over a plot and are described in detail in Breckenridge et al. (2006). The original plan was to use a helicopter that had a gyro-stabilizer system designed to allow for clear images to be taken even in moderate winds. However, the original helicopter was designed and built at a location near sea level. When this UAV was tested at the INL site at an elevation of about $1500 \mathrm{~m}$, it did not have sufficient lift to fly. Wind became a factor on the days the UAVs were tested after about 1000 hours. Early morning winds were calm, but by midafternoon, the helicopter often had to fly in winds up to $25 \mathrm{~km} \cdot \mathrm{h}^{-1}$. This made for difficult landings that required a high degree of skill by the operator.

The helicopter had a flight-time limitation of about $15 \mathrm{~min}$ because of its fuel capacity and camera memory. After flying each plot, imagery was downloaded from the camera to a portable computer and the operators immediately ensured that good images were acquired from each of the four subplots. On average, 30 images were collected over each plot during flights that averaged $5 \mathrm{~min}$.

\section{Field Data Collection}

Cover type values for shrub, dead shrub, grass, forb, litter, and bare ground were evaluated in the field using a point-frame method (Floyd and Anderson 1982). The frame had a rectangular design of $0.5 \times 1 \mathrm{~m}$. The point-frame method uses two sets of thin fly-fishing backing line (bright orange) superimposed over each other $5 \mathrm{~cm}$ apart. The frame was typically located $1.2 \mathrm{~m}$ above the ground and the observer looked down between the two sets of strings and aligned them like crosshairs in a rifle scope. Field values were collected within $1 \mathrm{~d}$ of the second helicopter flight and within $1 \mathrm{wk}$ of the fixed-wing flight during the second week of July. For each of the 28 field plots, $50 \%$ of each plot was read using a random number grid to identify the location to be sampled. An observer identified the cover type using the point-frame method and called the type out to a recorder that input the information into a handheld data recorder (Breckenridge et al. 2006). The plots were read over a 1-wk period. All field observers went through training and quality checks on test plots before reading the actual field plots to ensure consistency. Usually it took about $1 \mathrm{~d}$ to read the four subplots within a field plot. To minimize fatigue, observers rotated between plot observation and data recording after reading a subplot.

\section{Image Manipulation and Processing}

Images were downloaded from the UAV cameras into a portable computer at the end of each flight. The clearest and most nadir images were selected for analysis. Each image was oriented the same way and cropped to the smallest rectangle possible without removing any information inside the plot using a process described in Breckenridge et al. (2006). The rotated, cropped, and matched images were then imported into image analysis software called SamplePoint.

SamplePoint is a software program developed by the US Department of Agriculture Agricultural Research Service (USDA-ARS) in Cheyenne, Wyoming, and is used to assess vegetation cover on images (Booth et al. 2006a). Images were analyzed using a computer-based ocular process to identify the vegetation type on the fixed-frame photos. For the helicopter imagery, a $10 \times 10$ grid (100 points) was overlaid on each subplot image and the vegetation cover was identified at each 
Table 1. UAV ${ }^{1}$ helicopter and fixed-wing imagery values and field values collected in July.

\begin{tabular}{|c|c|c|c|c|c|c|c|c|c|c|c|c|}
\hline \multirow[b]{2}{*}{ e } & \multicolumn{6}{|c|}{ July helicopter UAV and field values } & \multicolumn{6}{|c|}{ July Fixed-wing UAV and field values } \\
\hline & $n$ & $\begin{array}{l}\text { Mean } \\
\text { imagery } \\
\text { values } \\
(\mathrm{SD})\end{array}$ & $\begin{array}{c}\text { Mean field } \\
\text { values (SD) }\end{array}$ & $\begin{array}{c}\text { Test of } \\
\text { equality of } \\
\text { variances } \\
P \text {-value }{ }^{2}\end{array}$ & $\begin{array}{c}\text { Mean } \\
\text { difference } \\
\text { IV - FV } \\
\text { (SD) }\end{array}$ & $\begin{array}{c}\text { Test of } \\
\text { means of } \\
\text { Differences } \\
P \text {-value }\end{array}$ & $n$ & $\begin{array}{c}\text { Mean } \\
\text { imagery } \\
\text { values (SD) }\end{array}$ & $\begin{array}{c}\text { Mean field } \\
\text { values (SD) }\end{array}$ & $\begin{array}{c}\text { Test of } \\
\text { equality of } \\
\text { variances } \\
P \text {-value }\end{array}$ & $\begin{array}{c}\text { Mean } \\
\text { difference } \\
\text { IV - FV } \\
\text { (SD) }\end{array}$ & $\begin{array}{c}\text { Test of } \\
\text { means of } \\
\text { differences } \\
P \text {-value }\end{array}$ \\
\hline Shrub & 7 & $22.0(11.2)$ & $12.7(4.8)$ & 0.008 & $9.2(7.4)$ & 0.017 & 7 & $21.7(10.1)$ & $12.7(4.8)$ & 0.055 & $9.0(7.7)$ & 0.021 \\
\hline Dead shrub & 7 & $8.5(3.6)$ & $10.1(5.0)$ & 0.372 & $-1.6(3.7)$ & 0.299 & 7 & $5.2(2.8)$ & $10.1(5.0)$ & 0.058 & $-4.9(3.1)$ & 0.006 \\
\hline Litter & 7 & $9.9(1.9)$ & $9.9(3.5)$ & 0.171 & $0.0(3.0)$ & 0.962 & 7 & $6.1(2.7)$ & $9.9(3.5)$ & 0.512 & $-3.8(3.3)$ & 0.022 \\
\hline Bare ground & 7 & $19.0(10.0)$ & $19.8(13.8)$ & 0.045 & $-0.8(5.1)$ & 0.690 & 7 & $20.5(11.6)$ & $19.8(13.8)$ & 0.067 & $0.7(3.1)$ & 0.567 \\
\hline
\end{tabular}

${ }^{1} \mathrm{UAV}$ indicates unmanned aerial vehicle; $n$, number of observations; IV, image value; FV, field value.

${ }^{2}$ Values in bold type are significant at 0.05 .

grid point as one of eight types (shrub, dead shrub, grass, forb, litter, bare ground, shadow, or outside). For the fixed-wing imagery, an analysis was attempted at the subplot level using the $10 \times 10$ grid; however, there was too much distortion in the image to make an accurate assessment. Thus, the fixed-wing imagery was read at the total plot level using a $16 \times 16$ grid that allowed for about 64 points to be read in each subplot with 256 total points per plot.

It took about a week to become sufficiently proficient in SamplePoint to read the images. During the initial stages, it took $12-20 \mathrm{~min}$ to read a 100 -point image. Within a few days, the time required to read an image was reduced to $5-7 \mathrm{~min}$. Details on the use of SamplePoint are available in Booth et al. (2006a) and Breckenridge et al. (2006).

If the cover types at a point could not be determined (due to shadow) or if the point fell outside of the corners of the subplots, it was recorded as shadow or "outside" and considered unknown. Data from each image were normalized to account for unknown values so that the remaining six vegetation types sum to $100 \%$ for each image. The number of points recorded as outside was higher for the fixed-wing UAV imagery because the entire plot using the $16 \times 16$ grid was evaluated. The largest shadow and outside values were, respectively, $5(2.2 \%)$ and 78 $(66 \%)$ of the 225 data points. The shadow values were probably not great enough to significantly alter total plot cover results. The outside values were large because points that fell in the 1-m walkway space between subplots were recorded as outside values. With the outside values removed, there were still 159 values read on average for each plot. For the $10 \times 10$ helicopter images at the subplot level, the average shadow and outside values were $1.8 \%$ and $6.4 \%$, respectively, and thus did not have a significant impact on the overall plot data.

\section{Data Analysis}

A series of analyses were conducted to assess how well the UAV imagery method compared with the field method for assessing percentage of cover for the six vegetation types. An assumption made for this study was that the field method of estimating percentage of cover was most representative of the true values and it was considered the standard against which the imagery values were compared.

Statistical assessments were conducted to evaluate how well the imagery collection method compared to the field method.
Relative accuracy in measurement was assessed by considering the two component parts of measurement error: precision and accuracy (also called bias; Blackwood and Bradley 1991). Precision was measured first by comparing variances between the methods; accuracy was then assessed by using paired $t$ tests. Before running the statistical tests, we checked normality using histograms and normal probability plots. The distribution of the data appeared to satisfy the assumption of normality.

Once the normality assumption was verified, the variance caused by the measurement method (field or imagery) was separated from other sources of variability (e.g., among vegetation types). Grubbs $(1948,1973)$ specifies an applicable model that identifies the different sources of variance (Blackwood and Bradley 1991). Under Grubbs' model, and assuming a bivariate normal distribution for the paired data, Maloney and Rastogi (1970) have shown that Pitman's test (Pitman 1939) applied to the observed variance in measurement (i.e., the sum of the field and imagery variances) is also a test of the relative precision of the two methods. More descriptive details of the statistical approach have been described by Blackman and Bradley (1991) and Breckenridge (2007). Statistical analyses were conducted on the UAV imagery and field data using a statistical software package called Statistica (Version 7.1).

\section{RESULTS}

Mean values for the imagery and field data and the results of the statistical evaluations for both precision (as tested by an evaluation of the variances) and accuracy (as tested by an evaluation of the mean of the differences) were evaluated (Table 1). In presenting and discussing results, the helicopter data will be addressed first because they were collected within a week of when the field data were collected. The fixed-wing data will then be presented and discussed; these data were collected 2 wk earlier than the field data. The reason for the 2 wk difference was because the same UAV operator was used for both flights. Given what was learned from this effort, it would be preferable to collect the fixed-wing data in $1 \mathrm{~d}$ and the helicopter data in $2 \mathrm{~d}$, all in the same week. This small difference in time between fixed-wing data collection and the field data did make a difference because some of the early season forbs were already in senescence. Phenology of the plant 
communities in high desert ecosystems can change quickly, especially in the month of July.

\section{Evaluation of Precision between Methods}

The first analysis conducted was to determine if there was a difference in precision between methods using the Pitman test (Pitman 1939). For the July helicopter data there was a significant difference for shrub $(P=0.008)$ and bare ground $(P=0.045$; see Table 1$)$. For the fixed-wing UAV, there was no significant difference for any cover types. The conclusion from the evaluation is that, although there are a limited number of cases in which statistically significant differences in variances exist, there was not enough significance in variances to indicate a difference in precision between the two UAV measurements and the field method.

\section{Evaluation of Accuracy Between Methods}

A separate paired $t$ test was used to test that the mean of the differences between the field and imagery values was equal to zero (see Table 1). For the July helicopter data, there was a significant difference only for shrub $(P=0.017$; Breckenridge 2007). For the fixed-wing UAV system, there were differences in results for shrub $(P=0.021)$, dead shrub $(P=0.006)$, and litter $(P=0.022$; see Table 1$)$.

\section{Decoy Evaluation}

Decoys dressed to simulate a male sage grouse along with a few females were placed around the plots (Fig. 2). This part of the study, added after discussion with a wildlife biologist interested in whether the grouse could be seen from a fixed-wing UAV platform, is only a proof-of-concept evaluation. The placement was designed to simulate how male and female sage grouse would interact on a lek during the spring strutting season. Decoy evaluation data from the helicopter and fixed-wing UAVs were recorded using an ocular method. Imagery was evaluated to determine if decoys randomly placed around subplots could be identified. Data from the helicopter were not evaluated because this platform is not a viable system for evaluation of wildlife due to the high noise factor.

Imagery from the fixed-wing UAV was evaluated at three different heights: 76, 153, and $305 \mathrm{~m}$ AGL. The results were recorded and compared to the known field values for decoy location and sex for each subplot. For the 76-m AGL imagery, both the male and female decoys could be identified by a skilled observer. An example of how the decoys looked for Plot 7 is shown in Figure 2. The fixed-wing imagery from early June was obtained at $153 \mathrm{~m}$ and $305 \mathrm{~m}$ AGL. Because vegetation was much greener in June and the imagery was collected $1 \mathrm{~d}$ after a rain event, and because the decoys have white on the breast that contrasted sharply with the green and brown cover, the decoys showed well. For the 153-m AGL imagery, all the male decoys and $60 \%$ of the female decoys could be detected. For the $305-\mathrm{m} \mathrm{AGL}$ imagery, over $90 \%$ of the male decoys were detected, but only $10 \%$ of the female decoys could be identified. Thus, the fixed-wing imagery at 76, 153, and $305 \mathrm{~m}$ AGL provided a good platform to identify decoys roughly the size of male grouse if they were in full strutting display on a lek. Male grouse typically have a white patch of chest feathers about $25 \mathrm{~cm}$ across that makes them fairly easy to identify from
Table 2. Comparison of sage grouse decoy identification from images collected with a fixed-wing unmanned aerial vehicle.

\begin{tabular}{lcc}
\hline Collection $\left(\mathrm{m} \mathrm{AGL}^{1}\right)$ & Males identified $(\%)$ & Females identified $(\%)$ \\
\hline 73 & 100 & 80 \\
153 & 100 & 60 \\
305 & 90 & 10 \\
\hline
\end{tabular}

${ }^{1} \mathrm{AGL}$ indicates above ground level.

imagery. Females decoys do not have any special markings and are well camouflaged; as such, they were easily identified at 76 and $153 \mathrm{~m}$ AGL, but difficult to identify at $305 \mathrm{~m}$ AGL (Table 2).

Video imagery was evaluated to determine its use in assessing the presence of sage grouse-like decoys on rangelands. At $76 \mathrm{~m}$ AGL, it is possible for a trained observer to identify the white on the male decoys in only some of the plots because of the lack of image clarity. The imagery was too grainy to evaluate cover types. This is mostly because the technology at the time only allowed for streaming video to be collected. The video collected at $305 \mathrm{~m} \mathrm{AGL}$ was only of sufficient quality to identify the plot locations; it was not possible to see the decoys. For the 153-m AGL video, the plots and subplots were visible and some of the larger male decoys could be identified. However, because the video is a combination of pictures, there is quite a bit of blur to the image. The video may be a viable technology for assessment of sage grouse and cover type, but only if it is flown at a lower elevation or a more sophisticated system is used that can zoom in during flight.

\section{DISCUSSION}

\section{Fixed-Wing Imagery Values}

Vegetation cover was analyzed using the fixed-wing UAV. Table 1 and Figure 4 show the comparison between the field and imagery values for cover type assessment from the fixedwing platform. When compared with field values, the fixedwing platform was just slightly over for bare ground $(+0.7 \%)$, over for grass $(+7.6 \%)$, and under for forb $(-8.6 \%)$; none of these differences were significant. The significant differences between mean values for shrub $(+9.0 \%)$, dead shrub $(-4.9 \%)$, and litter $(-3.8 \%)$ are very similar to the patterns noted from the helicopter values (Fig. 1). By the time of the July flights, many of the forbs had passed their peak and had senesced and/ or were located under the shrubs, making them very difficult to spot unless the observer was on the ground directly above the vegetation. The results of the helicopter and fixed-wing values suggest that if individual values for shrubs or forbs are needed, a different approach should be selected.

The Nevada Wildlife Federation (2002) and Connelly et al. (2000) found that the ideal sagebrush cover type values in Wyoming big sagebrush and basin big sagebrush communities similar to the communities where the study plots were located are 15-25\% shrub (Hagen et al. 2007). They also found that $10 \%$ or more forb cover was desirable for sage grouse. The cover values for vegetation obtained from the UAV imagery should be useful to support the recommendations for sage grouse habitat noted above. These values compare favorably with recommendations presented in Hagen et al. (2007). Thus, 
UAV platforms may have value for collecting information for sage grouse habitat if exact cover type values are not needed. Evaluation to determine if this level of data is sufficient for habitat assessment may present opportunities for future research for both wildlife and range scientists. This is because there is often a symbiotic relationship established between shrubs and forbs in rangeland communities. As long as the percentage of shrub does not exceed desirable limits, UAV cover type values for shrubs and forbs may be a reasonable approach for collecting habitat and forage information for some sagebrush obligate species.

The fixed-wing platform was not flown below $76 \mathrm{~m}$ AGL because of concerns that the platform might lose altitude during sharp banking maneuvers. The aircraft had expensive navigational equipment on board that needed to be protected; thus, risky maneuvers were minimized. After the flight was completed, it was noted that on average the UAV never lost more than a few meters in the banked turns; thus, for future flights it could be possible to fly at as low as $30 \mathrm{~m}$ AGL. Another option identified after we collected our data was to fly lower over the plots and then go up to a greater height AGL during turns to increase the margin of safety. The lower flights would have produced better images.

The overall size of the imagery from the three fixed-wing altitudes was about $10 \times 15 \mathrm{~m}$ for the $76-\mathrm{m}$ AGL height, $18 \times 24 \mathrm{~m}$ for the $153-\mathrm{m}$ AGL height, and $70 \times 90 \mathrm{~m}$ for the 305-m AGL height. If the imagery was not of sufficient size to meet the requirements of a land management agency, then imagery would have to be mosaicked together to cover the larger areas and this could add time and expense to the image analysis process.

The cost of the fixed-wing system used in this study is about $\$ 30000$. This value is fairly high for a natural resource study because the system was designed to meet US Department of Defense (DoD) requirements. The system had autopilot, a GPS, and a high-end camera. A similar system in 2010 dollars without autopilot would only cost about $\$ 15000$. However, without autopilot, it would be difficult to stay on a defined flight line. The objectives of the study would define the type of equipment needed.

Fixed-wing imagery was used to evaluate how well decoys could be identified at three different elevations: 76, 153, and $305 \mathrm{~m}$. UAV fixed-wing missions were flown for over $1 \mathrm{~h}$ (fuel was available to fly up to $4 \mathrm{~h}$ ). Collected imagery was limited by memory space on the camera chip. Technology has already advanced to address this concern.

The results discussed above suggest that fixed-wing platforms could have application for identification of sage grouse on a lek. However, several issues need to be evaluated in future research. One is the height and shape of the aircraft and its similarity to the silhouette of a bird of prey. For both the 76and 153-m AGL flights, the identification of both the male and female decoys was possible; however, there is a high probability that flights at these elevations would impact the birds on a lek. For the $305-\mathrm{m}$ AGL flights, $90 \%$ of the males were identified but only $10 \%$ of the females. It may be possible to use UAV flights with greater heights AGL such as this for sage grouse evaluations because it was difficult to spot and hear the plane at this altitude. It also may be possible to use other UAV platforms that have different designs so the silhouette would

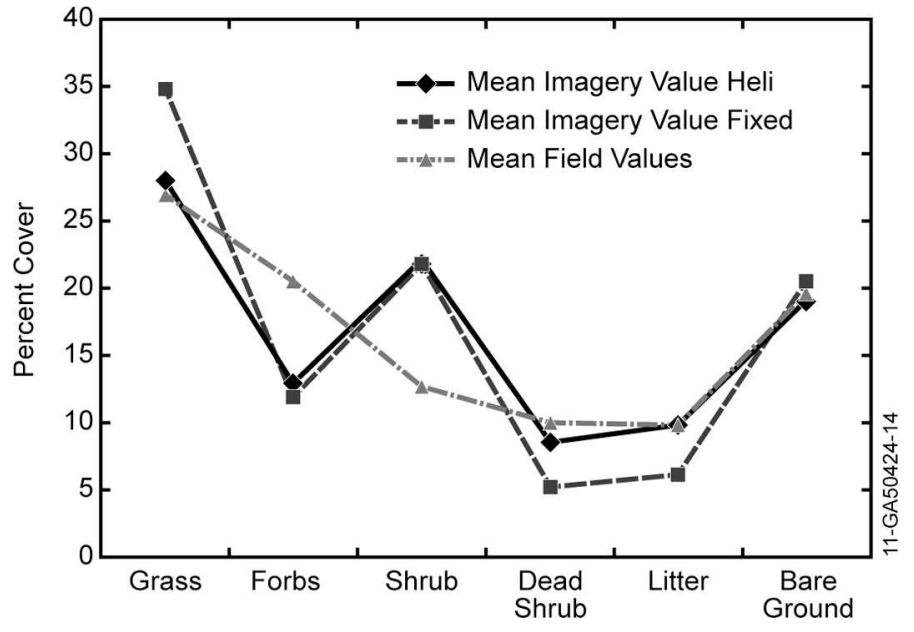

Figure 4. Line plot for July fixed-wing and helicopter unmanned-aerialvehicle mean imagery vs. field values.

not resemble a bird of prey and would not impact grouse activity on a lek. This could be a topic to be evaluated by future researchers.

\section{Helicopter Imagery Values}

Figure 4 shows a comparison of the UAV helicopter and field values from early July. The helicopter imagery shows a high degree of agreement with the field values for dead shrub, grasses, litter, and bare ground. Shrub cover was often overestimated by the imagery approach and forbs were underestimated. It is likely that forbs were hard to identify because the imagery was acquired past their peak growth period.

The cost of the helicopter UAV system was about $\$ 3000$. The size and portability of the system allow it to fit in the back of a pickup truck and be taken to a variety of field locations. The ability to take off and land on a $0.9 \times 1.5 \mathrm{~m}$ pad makes it possible to use almost any dirt road or patch of bare ground as a launch site.

\section{Video Imagery}

The video system used in both UAVs is a through-the-lens streaming video system. Both systems were designed to allow for remote transmission of data to a ground receiver, allowing real-time viewing of imagery. The imagery collected for this study was not of a high enough quality to assess vegetative cover. Newer technology is being developed to allow for individual frames to be separated, thus producing a much clearer image. There were situations where the video was zoomed for other missions that produced higher-quality imagery; thus, it is possible to acquire better imagery. As a proof-of-concept, this project showed it is feasible to collect video imagery for evaluation of large tracts of land, but it was not useful for evaluation of vegetative cover or decoys in this study. The potential use of imagery collected from UAVs may have greater application with improved video collection systems and for imagery collected at either a lower elevation AGL or with a system that has zoom capability. Video imagery is generally not better than the quality from still camera photography. Video imagery collected by UAVs may have 
Table 3. A comparison of the time required to collect unmanned-aerial-vehicle data sets and field data sets.

\begin{tabular}{|c|c|c|c|}
\hline Activity & $\begin{array}{l}\text { Helicopter UAV time } \\
\text { requirement }(\mathrm{h})\end{array}$ & $\begin{array}{l}\text { Fixed-wing UAV time } \\
\text { requirement }(\mathrm{h})\end{array}$ & $\begin{array}{l}\text { Field method time } \\
\text { requirement }(\mathrm{h})\end{array}$ \\
\hline Set up 7 plots (4 subplots/plot) & 5 & 5 & 4 \\
\hline Set up and collect imagery from UAV platform & 32 & 4 & \\
\hline Collect field data using point frame ( $50 \%$ of all 28 subplots) & & & 72 \\
\hline \multicolumn{4}{|l|}{ Image processing } \\
\hline \multicolumn{4}{|l|}{ Fixed-wing (30 $\min \times 7$ plots $)$} \\
\hline Helicopter (12.5 min $\times 28$ subplots) & 5.8 & 3.5 & \\
\hline Analyze data and report ( $60 \mathrm{~min} \times 7$ plots) & 7.0 & 7.0 & 7.0 \\
\hline Totals & 49.8 & 23.5 & 83 \\
\hline
\end{tabular}

applications for management of natural resources, especially in situations with high contrast (e.g., identification of total shrub cover or wildlife presence with snow cover) and should be evaluated by future studies.

\section{Comparison of Time Among Methods}

The UAV methods have an advantage over conventional field methods relative to the time required to set plots and collect and analyze data. Table 3 is a summary of the times required to collect data from both the UAV and field methods. These are the typical times that the researchers needed to complete tasks but do not include the times required for training. The time for collection of field data could in general be reduced by experienced field crews, but it would be very difficult to reduce the time below that required to collect the imagery with the UAVs. For the fixed-wing system, the actual flight time was $75 \mathrm{~min}$ and over 700 images were collected. For the helicopter, the total flight time was $40 \mathrm{~min}$ and more than 210 images were collected. The remainder of the time was spent on setup, safety checks, data transfer, and moving between plots for the helicopter operation.

One of the most difficult tasks with the UAV process was selecting the best image for analysis. The UAV platforms allowed for the collection of a large number of images quickly within a day, thereby minimizing phenological differences between sites. The UAV process is almost opposite of traditional field data collection where extensive periods of time are needed in the field to collect data. The UAV process maximizes data collection during the optimal time for sampling.

\section{RECOMMENDATIONS AND CONCLUSIONS}

Comparison of fixed-wing and helicopter UAV technology against field values shows good agreement for measurement of bare ground, one of the single most important cover indicators for assessment of rangeland health. One of the reasons that bare ground is considered important is that it integrates how the range has been managed or impacted by climatic factors over a long period of time. If an area has been overgrazed or there has been a prolonged drought, desirable vegetation cover (both living and dead) will be reduced and the amount of bare ground will increase. All of the plots selected for these studies were in areas that have not been grazed for many years or impacted by unusual climatic conditions and were in fairly good condition. If bare ground can be evaluated by UAVs in conditions where the rangeland is fairly healthy, there is good potential that they will be effective in an unhealthy area where the amount of bare ground is more extensive. The values determined for the seven plots were within $1 \%$ of the field values (field value 19.8\%, helicopter 19.0\%, and fixed-wing UAV $20.5 \%$ ); thus, there was good agreement for bare ground values among methods.

As this study shows, different types of UAVs may be more effective in certain situations. If a high degree of detail and accuracy is desired to meet the study objectives, then a helicopter UAV may be a better platform because helicopters can fly at lower heights AGL and therefore collect higher quality images. If the objectives are to collect imagery for a much larger area (e.g., an allotment) to assess landscape level changes, then a fixed-wing system is probably more appropriate. Fixed-wing UAVs can fly much longer missions (4-8 h compared with $15 \mathrm{~min}$ for the helicopter used in this study). This allows for the collection of a large amount of data over an extensive area during the same phenological time that can be analyzed in the office at a later time. This is almost the opposite case for the same amount of field data, which requires an extensive amount of time (days or weeks) to collect. Future research should focus on establishing the optimum image size at the ideal elevation AGL for collecting rangeland data that meets land management agencies' requirements. If the agencies need larger-scale imagery, mosaicking could be a viable option (Laliberte et al. 2010). Research should also focus on identifying the best total system for conducting rangeland health assessments (platform, camera, and navigational instruments).

The fixed-wing UAV was initially flown at 153 and $305 \mathrm{~m}$ AGL. These elevations produced marginal images that were too blurry to enlarge for evaluation. The 76-m AGL elevation provided imagery that was of good quality, but better images may be collected at lower elevations AGL; however, the balance between image overlap and airspeed needed to keep the craft in the air needs to be considered.

UAV systems do require some setup time before flight. The more instrumentation that is located on the platform, the greater the time requirement for preprogramming flight information and system setup. The helicopter UAV system was easy to set up and is ideal for collection of detailed information for small areas but requires more training to operate, especially in areas where landing areas are limited, 
terrain is highly variable, or winds are a factor. Future fixedwing systems could be optimized to operate in remote areas using hand or mechanical launch and parachute landing systems. These can be flown over much larger areas.

Shadow and time of day should be evaluated against study objectives to determine if they are significant. These variables could be optimized by future studies. Shadows were present in all the images but were not a major concern, with the exception of separation of forbs from shrubs. For both UAV platforms, it was best to fly early in the day before the winds developed; however, this resulted in larger shadows. To minimize shadows, it is best to fly during the day between 1000 hours and 1400 hours.

Additional studies could be conducted to address the optimum phenological times for collecting the best data for analysis to meet land managers' objectives. If agencies and scientists want to know data about specific species, a study would need to focus on flying UAV platforms at various times during the growing season. For example, if it is important to secure accurate shrub data, flights could be timed during periods where there was a slight amount of snow cover to enhance contrast between shrubs and background.

Image processing for this study used mostly a manual, ocular approach. Future research to develop a more automated system to process both fixed frame and video imagery would enhance the application and reduce error. This would improve the usefulness of image analysis systems for rangeland management. Evaluation of newer video collection systems should be a high priority for future work. However, newer video will probably never be better than a high-quality still camera system.

Additional research needs to be conducted to see if sage grouse react to UAVs flying over leks in a similar manner to a raptor that might be preying on the grouse. The AGL height and the shape of the UAV are both factors that should be assessed. It will also be important to evaluate whether UAVs are accurate in monitoring the presence of sage grouse on a lek. The best way to evaluate this could be to team up with a sage grouse field survey in the spring and fly the UAV over a lek where there are actual counts being collected. The field observer could also evaluate the effect the UAV flight has on bird behavior.

UAV platforms, camera systems, and image processing systems are continually being improved; thus, future systems will have reduced weight, increased data storage, improved picture quality, improved image processing systems, and GPS guidance systems. These changes will allow for continuous improvements in data quality. Because there will always be a demand for high-quality reliable data for making and defending management decisions, and because of the shortage of field workers and rising labor costs, UAVs may provide costeffective options for collecting information for management of vast western rangelands.

\section{MANAGEMENT IMPLICATIONS}

Results from collecting vegetation data using fixed-wing and helicopter UAVs show these platforms can be effective for collecting high-resolution, near-earth imagery. These platforms can fill an important niche between the field worker and satellite systems. They are highly mobile, can cover vast remote areas with ease, involve relatively low safety risk with proper training, and reduce the time spent in the field collecting data. UAV technology has advanced to carry a sufficient payload to acquire high-quality imagery over fairly large areas. It is important to match the objectives of an organization against capabilities that a UAV system can provide. For example, there may be scientific or management reasons to combine shrubs and/or forbs in an assessment of habitat and forage for sage grouse, as suggested by some scientists (Hagen et al. 2007). This study focused on using UAV systems for assessment of vegetation cover and, to a lesser extent, identification of wildlife decoys. The technology has much greater application for collection of many other types of data needed by land managers, including off-road vehicle use, riparian area condition, exotic species encroachment, fire mapping, landscape changes, and law enforcement.

An interagency study should be developed as a joint effort with the appropriate agencies that would benefit from using UAV systems to enhance management of their lands (e.g., BLM, US Department of Agriculture Forest Service, DOE, DoD, and National Park Service). A study designed to focus on data collection that directly supports their mandated management objectives would improve the possibility of having this technology accepted by both line management and research staff. Greater involvement with land management agency scientists will improve the understanding of the current challenges and opportunities made available by UAV systems.

\section{ACKNOWLEDGMENTS}

The authors would like to extend sincere thanks to Mark McKay and Matthew Anderson for piloting the helicopter and fixed-wing systems and collecting imagery; Ron Rope, Ryan Hruska, Sera White, and Angie Smith (INL), Marilynne Manguba (The Nature Conservancy), and Anthony Piscitella, Chase Eckersell, and Katherine Schoellenbach (students) for assisting in collection of field data, reading imagery, and assisting with edits; Terry Booth and Sam Cox (USDA-ARS) for developing SamplePoint and assisting in its use; Dr Larry Blackwood for providing guidance with statistical analysis; and Dr Don Crawford (University of Idaho) and Sue Vilord, Jackie Hafla, and Roger Blew (S. M. Stoller Corporation) for technical guidance and assistance with providing equipment and quality control checks for field activities.

\section{LITERATURE CITED}

Anderson, J. E., and K. E. Holte. 1981. Vegetation development over 25 years without grazing on sagebrush-dominated rangeland in Southeastern Idaho. Journal of Environmental Management 34:25-29.

Anderson, J. E., and R. S. Inouye. 1999. Long-term vegetation dynamics in sagebrush steppe at the Idaho National Engineering and Environmental Laboratory. Idaho Falls, ID, USA: Environmental Science and Research Foundation. $58 \mathrm{p}$.

Anderson, J. E., K. T. Ruppel, J. M. Glennon, K. E. Holte, and R. C. Rope. 1996. Plant communities, ethnoecology, and flora of the Idaho National Engineering Laboratory. Idaho Falls, ID: Environmental Science and Research Foundation, ESRF-005. $110 \mathrm{p}$.

BendeR, G. L. 1982. Reference handbook on the deserts of North America. Westport, CT, USA: Greenwood Press. 594 p.

Blackwood, L. C., and E. L. Bradley. 1991. An omnibus test for comparing two measuring devices. Journal of Quality Technology 23:12-16. 
BonHam, C. D. 1989. Measurements for terrestrial begetation. New York, NY, USA: John Wiley \& Sons. $319 \mathrm{p}$.

Booth, D. T., S. E. Cox, and R. D. Berryman. 2006a. Point sampling digital imagery with 'SamplePoint'. Environmental Monitoring and Assessment 123:97-108.

Booth, D. T., S. E. Cox, T. W. Meikle, and C. Fitzgerald. 2006b. The accuracy of ground-cover measurements. Rangeland Ecology \& Management 59:179-188.

Booth, D. T., AND P. T. Tueller. 2003. Rangeland monitoring using remote sensing. Arid Land Research and Management 17:455-467.

BRECKENRIDGE, R. P. 2007. Improving rangeland monitoring and assessment: integrating remote sensing, gis and unmanned aerial vehicle systems [dissertation]. Moscow, ID, USA: University of Idaho. 121 p.

Breckenridge, R. P., and M. E. Dakins. 2011. Evaluation of bare ground on rangelands using unmanned aerial vehicles: a case study. GlScience \& Remote Sensing 48:74-85.

Breckenridge, R. P., M. Dakins, S. Bunting, J. L. Harbour, and R. D. Lee. 2006. Employing unmanned aerial vehicles for monitoring habitat in sagebrushsteppe ecosystems. In: J. R. Greer [EDS.]. Proceedings of the 11th Biennial USDA Forest Service Remote Sensing and Applications Center Conference; 24-28 April 2006; Salt Lake City, UT, USA. Salt Lake City, UT, USA: USDA Forest Service.

Breckenridge, R. P., W. G. Kepner, and D. A. Mouat. 1995. A process for selecting indicators for monitoring conditions of rangeland health. Environmental Monitoring and Assessment 36:45-60.

BRISke, D. D., S. D. Fuhlendorf, And F. E. Smeins. 2005. State-and-transition models, thresholds, and rangeland health: a synthesis of ecological concepts and perspectives. Rangeland Ecology \& Management 58:1-10.

Brower, J. E., J. H. ZAR, and C. N. Von Ende. 1990. Field and laboratory methods for general ecology. 3rd ed. Dubuque, IA, USA: Wm. C. Brown Publishers. 237 p.

Bunting, S. C. 2002. Natural and prescribed fires in big sagebrush stepperesponse of individual species and implication to burning practices. Available at: http://www.rangenet.org/trader/2002_Elko_Sagebrush_Conf.pdf. Accessed 19 June 2006.

Bunting, S. C., B. M. Kilgore, and C. L. Bushey. 1987. Guidelines for prescribed burning sagebrush-grass rangelands in the northern Great Basin. Ogden, UT, USA: US Department of Agriculture, Forest Service, Intermountain Forest and Range Experiment Research Station, General Technical Report INT-231. 33 p.

Carroll, C. R., J. Belnap, R. Breckenridge, and G. Meffe. 1999. Ecosystem sustainability and condition. In: W. T. Sexton, A. J. Malk, R. C. Szaro, and N. C. Johnson [EDS.]. A common reference for ecosystem management. Volume II. New York, NY, USA: Elsevier Science. p. 583-598.

CoLKET, E. C. 2003. Long-term vegetation dynamics and post-fire establishment patterns of sagebrush steppe [thesis]. Moscow, ID, USA: University of Idaho. $144 \mathrm{p}$.

Connelly, J. W., and C. E. Braun. 1997. Long-term changes in sage-grouse Centrocercus urophasianus populations in western North America. Wildlife Biology 3:229-234.

Connelly, J. W., K. P. Reese, R. A. Fischer, and W. L. Wakkinen. 2000. Response of a sage grouse breeding population to fire in southeastern Idaho. Wildlife Society Bulletin 28:90-96.

Cook, C. W., And J. StubBendieck. 1986. Range research: basic problems and techniques. Denver, CO, USA: Society for Range Management. 317 p.

Crawford, J. A., R. A. Olson, N. E. West, J. C. Mosley, M. A. Schroeder, T. D. Whitson, R. F. Miller, M. A. GregG, and C. S. Boyd. 2004. Ecology and management of sage-grouse and sage-grouse habitat. Journal of Range Management 57:2-19.

[DOE] US Department of Energy. 1994. National environmental research parks. Washington, DC, USA: DOE, Office of Energy Research, DOE/ER-0615. 183 p.

[FAA] Federal Aviation Administration. 2008. Interim operational approval guidance 08-01: unmanned aircraft systems operations in the U. S. national airspace system. Washington, DC, USA: Aviation Safety Unmanned Aircraft Program Office, AIR-160. $18 \mathrm{p}$.

FLoYd, D. A., AND J. E. Anderson. 1982. A new point frame for estimating cover of vegetation. Vegetatio 50:185-186.

Forman, A. D., AND J. R. HafLA. 2005. Common plants of the INL. STOLLER-ESER81. Idaho Falls, ID, USA: Environmental Surveillance, Education and Research
Program. 125 p. Available at: http://www.stoller-eser.com/CMP/Plant_handbook/ index.asp. Accessed 7 April 2007.

French, N. R., and J. E. Mitchell. 1983. Long-term vegetation changes in permanent quadrants at the Idaho National Engineering Laboratory site. Moscow, ID, USA: University of Idaho, College of Forestry, Wildlife and Range Sciences. Bulletin 36. $42 \mathrm{p}$.

GRUBBS, F. E. 1948. On estimating precision of measuring instruments and product variability. Journal of the American Statistical Association 43:243-264.

GRUBBS, F. E. 1973. Errors of measurement, precision, accuracy and the statistical comparison of measuring instruments. Technometrics 15:53-66.

Hagen, C. A., J. W. Connelly, and M. A. Schroeder. 2007. A meta-analysis of greater sage-grouse Centrocercus urophasianus nesting and brood-rearing habitats. Wildlife Biology 13(Suppl. 1):27-35.

Hardin, P. J., And M. W. JaCkSon. 2005. An unmanned aerial vehicle for rangeland photography. Rangeland Ecology \& Management 58:439-442.

Hardin, P. J., M. W. Jackson, V. J. Anderson, and R. Johnson. 2007. Detecting squarrose knapweed (Centaurea virgata Lam. ssp. Squarrosa Gugl.) using a remotely piloted vehicle: a Utah case study. GIScience and Remote Sensing 44:203-219.

Johnson, D. E., M. Vulfson, M. Louhaichi, and N. R. HarRis. 2003. VegMeasure version 1.6 user's manual. Corvallis, OR, USA: Oregon State University, Department of Rangeland Resources, VegMeasure Project. $51 \mathrm{p}$.

KNICK, S. T., AND J. T. RotenBeRRY. 1995. Landscape characteristics of fragmented shrubsteppe habitats and breeding passerine birds. Conservation Biology 9:1059-1071.

Laliberte, A. S., J. E. Herrick, and A. Rango. 2010. Acquisition, orthorectification, and object-based classification of unmanned aerial vehicle (UAV) imagery for rangeland monitoring. Photogrammetric Engineering and Remote Sensing 76:661-672.

Maczko, K. A., L. D. Bryant, D. W. Thompson, and S. J. Borchard. 2004. Putting the pieces together: assessing social, ecological, and economic rangeland sustainability. Rangelands 26(3):3-14.

Mahalovich, M. F., and E. D. McArthur. 2004. Sagebrush seed (Artemisia ssp.) and plant transfer guidelines. Native Plants 5:141-148.

Maloney, C. J., and S. C. Rastogi. 1970. Significance test for Grubbs's estimators. Biometrics 26:671-676.

Mouat, D. A., and C. F. Hutchinson [eds.]. 1995. Desertification in developed countries. Dordrecht, The Netherlands: Kluwer Academic Publishers. 363 p.

National Research Council. 1994. Rangeland health: new methods to classify, inventory, and monitor rangelands. Washington, DC, USA: Committee on Rangeland Classification, The National Academies Press. 180 p.

National Transportation Safety Board. 2007. Aviation accident database \& synopses. Available at: http://www.ntsb.gov/ntsb/query.asp. Accessed 7 April 2007.

Nevada Wildlife Federation. 2002. Enhancing sage grouse habitat ... a Nevada landowner's guide. Available at: http://www.nvwf.org/. Accessed 5 April 2007.

Pedersen, E. K., J. W. Connelly, J. R. Hendrickson, and W. E. Grant. 2003. Effect of sheep grazing and fire on sage grouse populations in southeastern Idaho. Ecological Modelling 165:23-47.

Pellant, M., P. Shaver, D. A. Pyke, and J. E. Herrick. 2005. Interpreting indicators of rangeland health. Version 4. Denver, CO, USA: US Department of the Interior, Bureau of Land Management, National Science and Technology Center, Technical Reference 1734-6, BLM/W0/ST-00/001+1734/REV05. 122 p.

Pitman, E. J. G. 1939. A note on normal correlation. Biometrics 31:9-12.

Pyke, D. A., J. E. Herrick, P. Shaver, and M. Pellant. 2002. Rangeland health attributes and indicators for qualitative assessment. Journal of Range Management 55:584-597.

Quiter, M. C., AND V. J. Anderson. 2001. A proposed method for determining shrub utilization using low altitude/large scale aerial imagery. Journal of Range Management 54:378-381.

Rango, L. A., and A. S. Laliberte. 2010. Impact of flight regulations on effective use of unmanned aircraft systems for natural resource applications. Journal of Applied Remote Sensing 3, 033542. DOI: 10.1117/1.3216822.

Rango, L. A., A. Laliberte, J. E. Herrick, C. Winters, K. Havstad, C. Steele, and D. Browning. 2009. Unmanned aerial vehicle-based remote sensing for rangeland assessments, monitoring and management. Journal of Applied Remote Sensing 3:1-15. 
Rango, L. A., A. Laliberte, C. Steele, J. E. Herrick, B. Bestelmeyer, T. Schmugge, A. RoANHOURSE, AND V. JenKINS. 2006. Using unmanned aerial vehicles for rangelands: current applications and future potential. Environmental Practice 8:159-168.

Rickard, W. H., L. E. Rogers, B. E. Vaughan, and S. F. Liebetrau [eds.]. 1988. Shrubsteppe: balance and change in a semi-arid terrestrial ecosystem. New York, NY, USA: Elsevier. $272 \mathrm{p}$.

Smith, R. L. 1990. Ecology and field biology. 4th ed. New York, NY, USA: Harper Collins. $922 p$

[SRM] Society for Range Management, Task Group on Unity in Concepts and Terminology Committee Members. 1995. New concepts for assessment of rangeland condition. Journal of Range Management 48:271-282.
[USDI-BLM] US Department of the Interior, Bureau of Land Management. 1997. Standards for healthy rangelands and guidelines for livestock grazing management for the public lands administered by the Bureau of Land Management in the State of Wyoming. Cheyenne, WY, USA: US Department of the Interior, Booklet BLM/WY/AE-97-023+1020. $16 \mathrm{p}$.

WALKER, B. H. 1993. Rangeland ecology: understanding and managing change. Ambio 22:80-87.

Whitford, W. G. [Ed.]. 1986. Pattern and process in desert ecosystems. Albuquerque, NM, USA: University of New Mexico Press. $139 \mathrm{p}$.

ZAGER, P. 2006. UAVs and natural resources. Available at: http://www.fs.fed.us/ eng/rsac/RS2006/presentations/zager.pdf. Accessed 5 April 2007. 